and music rather than on history. Three lectures of interest to historians, however, were given late in 1964 and early in 1965. On October 9, 1964, Josef Hamm, of the University of Vienna, spoke on "The Eastern and Western Slavs and their Cultural Relations-an Austrian View." Two months later, on December 10, William Jenks, of Washington and Lee University, lectured on "National Party Ideologies during Austria's Constitutional Period." On January 21 of the following year, Ernst Papanek, of Queens College, gave a talk on "Austrian School Reform since 1918."

\title{
PROMOTIONS AND APPOINTMENTS
}

Gerald H. Davis was promoted to associate professor of history at Georgia State College in September, 1964.

Istvan Deak was promoted to assistant professor of history at Columbia University in the summer of 1964.

Frank Garosi was appointed assistant professor of history at Sacramento State College, California.

Paul Halpern, formerly a graduate student at Harvard University, was appointed assistant professor at Florida State University in September, 1965.

Bascom Barry Hayes, of Southwest Texas State College, was appointed assistant professor of history at the University of California at Riverside in July, 1965.

Arthur G. Haas was promoted to associate professor of history at the University of Tennessee in July, 1965.

Joseph Held has been appointed instructor of history at Newark College of Engineering.

Keith Hitchins, of Wake Forest College, has accepted an appointment as assistant professor of history and associate editor of the Austrian History Yearbook at Rice University.

Robert A. Kann, of Rutgers University, will be visiting professor at Princeton University in the spring semester of 1966.

Emile Karafiol was promoted to assistant professor of history at the University of Chicago in September, 1965. 
Edward P. Keleher, of Southern Illinois University at East St. Louis, was promoted to assistant professor of history in September, 1965.

Stanley B. Kimball was promoted to associate professor of history at Southern Illinois University at Edwardsville in the summer of 1964.

Béla K. Kirǎly has been appointed assistant professor of history at Brooklyn College.

Richard Laurence was appointed instructor of history at Stanford University in September, 1965.

Ivo J. Lederer, formerly of Yale University, joined the history faculty at Stanford University in September, 1965.

Alfred D. Low, formerly of Iowa Wesleyan College, has been appointed to the faculty of history at Marquette University.

Myron Low, formerly a graduate student at the University of Texas, has accepted an appointment as visiting instructor of history and associate editor of the Austrian History Yearbook at Rice University for 1965-66.

Rolland Ray Lutz, Jr., of Newark State College, was promoted to associate professor of history in September, 1965.

Woodford D. McClellan was appointed associate professor of history at the University of Virginia in September, 1965.

William J. McGill has been named chairman of the history department at Alma College.

George J. Prpic, of John Carroll University, has been promoted to associate professor of history.

J. Claude Roberts was at Sam Houston State College in 1964-65. In September, 1965, he returned to the history faculty of the European Division of the University of Maryland.

Kenneth W. Rock, formerly a graduate student at Stanford University, was appointed instructor of history at Colorado State University in September, 1965.

Gerard E. Silberstein, formerly of the State University of 
New York at Cortland, was appointed assistant professor of history at the University of Kentucky in September, 1964.

Sherman David Spector was promoted to associate professor of history and government at Sage College' in September, 1965.

Paul R. Sweet has been serving as American Consul General in Stuttgart, Germany, since November, 1963.

Glenn Torrey, of Kansas State Teachers College at Emporia, was promoted to professor of social sciences in September, 1965.

Solomon Wank was promoted to associate professor and made chairman of the history department at Franklin and Marshall College in the summer of 1965.

Stanley B. Winters was promoted to associate professor of history and appointed associate chairman of the department at Newark College of Engineering in September, 1965.

Joseph F. Zacek, formerly of Occidental College, was appointed assistant professor of history at the University of California at Los Angeles in July, 1965.

\section{PRIZES, FELLOWSHIPS, SCHOLARSHIPS, AND RESEARCH GRANTS}

Richard E. Allen, of Columbia University, did research in the fall of 1964 in Berne, Geneva, Paris, London, Amsterdam, The Hague, Vienna, Graz, Budapest, Debrecen, and Munich. He had a grant from the Inter-University Committee on Travel Grants to assist him in this work.

George Bárány, of the University of Denver, received summer research grants for 1964 from the American Council of Learned Societies and the Austrian Ministry of Education to continue his research on Count Stephen Széchenyi.

Thomas M. Barker, of the State University of New York at Albany, received a grant from the SUNY Research Foundation to complete his work on the Turkish siege of Vienna in 1683.

Frederick Dumin, of Washington State University, was 